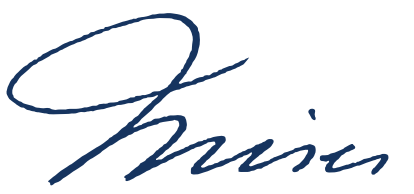

\title{
Carl Menger's revisited theory of capital in opposition to the Classical and Marginalist scholars
}

\author{
Samuel Fernandes Lucena Vaz-Curado I (1) 0000-0001-9071-5015 \\ Universidade Federal de Sergipe - Aracaju - Sergipe - Brasil
}

\begin{abstract}
Among several contributions, Carl Menger proposed a division of economic goods in orders. This sets the foundations for the Austrian capital theory, usually maintained as a complex of higher orders goods in a production process. Curiously, Menger dismissed this concept of capital, in favor of one used in common parlance. This change of view is often overlooked, but represents a turning point in the field of capital theory. This paper assesses how Menger's popular notion of capital differs from the scientific one. To achieve this goal, we investigate the concept of capital in Classical and Marginalist economists. One of the implications is that the popular concept is related to the theory of capitalism. Capital, as used in business language for economic calculations, is better suited for analyzing the capitalist system, as it captures the usage in monetary economies and business accounting.
\end{abstract}

Keywords: Capital Theory, Economic Calculation, History of Economic Thought, Marginalist Revolution, Austrian School of Economics.

\footnotetext{
${ }^{\mathrm{I}}$ Mestre em Economia pela Universidade Federal de Sergipe (UFS) e economista pela Universidade Federal de São Paulo (UNIFESP). E-mail: samuelvazcurado@gmail.com.
} 


\title{
La teoría revisada del capital de Carl Menger en oposición a los académicos clásicos y marginalistas
}

Resumen: Entre sus diversas contribuciones, Carl Menger propuso una división de los bienes económicos en órdenes. Esto sienta las bases de la teoría del capital austriaca, que generalmente se mantuvo como un complejo de bienes de orden superior en un proceso de producción. Curiosamente, Menger descartó este concepto de capital, y favoreció uno usado en la jerga común. Este cambio de visión suele pasarse por alto, pero representa un punto de inflexión en el campo de la teoría del capital. Este artículo evalúa en qué se diferencia la noción popular de capital de Menger de la científica. Para lograr este objetivo, investigamos el concepto de capital en economistas clásicos y marginalistas. Una de las implicaciones es que el concepto popular está relacionado con la teoría del capitalismo. El capital, tal como se usa en el lenguaje comercial para los cálculos económicos, es más adecuado para analizar el sistema capitalista, ya que captura el uso en las economías monetarias y la contabilidad empresarial.

Palabras Clave: Teoría del Capital, Cálculo Económico, Historia del Pensamiento Económico, Revolución Marginalista, Escuela Austriaca de Economía.

\section{A teoria revisada de capital de Carl Menger em oposição aos acadêmicos clássicos e marginalistas}

\begin{abstract}
Resumo: Entre outras contribuições, Carl Menger propôs uma divisão dos bens econômicos em ordens. Isso lançou as bases da teoria austríaca do capital, que se manteve como um complexo de bens de ordem superior em um processo de produção. Curiosamente, Menger descartou esse conceito de capital, e favoreceu outro usado na linguagem comum. Essa mudança de visão é frequentemente negligenciada, porém, representa um ponto de inversão no campo da teoria do capital. Esse artigo avalia como a noção popular de capital de Menger difere da visão científica. Nesse intento, investigamos o conceito de capital nos economistas clássicos e marginalistas. Uma das implicações é que o conceito popular está relacionado à teoria do capitalismo. O capital, tal qual usado na linguagem empresarial para os cálculos econômicos, é mais adequado para analisar o sistema capitalista, já que captura o uso nas economias monetárias e na contabilidade empresarial.
\end{abstract}

Palavras-chave: Teoria do Capital, Cálculo Econômico, História do Pensamento Econômico, Revolução Marginalista, Escola Austríaca de Economia. 


\section{Introduction}

Capital theory is undoubtedly the most controversial research field in Economics. Fisher (1896, p. 509) opens his investigation on capital by saying that "of all economic conceptions, few are more fundamental and none more obscure than capital". Walras (1954 [1874], p. 213) argues that "many authors are still confused and obscure in their writings" on capital theory. Menger (1888:1) admits that the character of capital is ambiguous and controversial.

Carl Menger is considered the founder of the Austrian School of Economics. Among other contributions, Menger (1871) proposed a division of economic goods in orders: lower-order goods satisfy human needs more directly, while higher-order goods only indirectly. Based on this, the Austrian capital theory is usually maintained as a complex of higher orders goods in a production process. Curiously, Menger dismissed this concept of capital, in favor of one used in common parlance.

Taking care not to resemble Keynes' (1936) wild duck, that dove too deep and got tangled down at the bottom, this paper investigates Menger's revisited concept of capital, in the context of the Classical and Marginalist economists. Since Adam Smith, the theory of capital as produced means of production has become the main line of thought. Having followed a similar path at first, Menger revisited the concept on a rather overlooked paper from 1888, representing a turning point in the field. Hicks (1974) roughly divides the theories of capital into two groups: the Fundists and the Materialists. Fetter (1900) recognizes two different approaches to capital even before Adam Smith: the first viewing it as concrete goods; the second, as the market value of goods. Menger (1888) adopts the latter - a concept of capital as understood in business language, not in economic science.

To assess the differences between the popular notion of capital and the conception of produced means of production, and the research field that it potentially opens (HODGSON, 2014; BRAUN, 2017), this article firstly approaches the Classical concept of capital as in Smith, Ricardo, and Stuart Mill. Then, it proceeds to investigate the Marginalist concept of capital, as in the three exponents of this tradition, Jevons, Menger, and Walras. Finally, this paper studies Menger's (1888) revisited theory of capital, a clear rupture from all the authors above, including Menger's writings in 1871.

The paper is divided into four sections, apart from the introduction. The second investigates the Classical concept of capital presented in Adam Smith, David Ricardo, and James Stuart Mill. The third analyzes the Marginalist theories of capital in William Stanley Jevons' and Leon Walras' works. The fourth studies Carl Menger's concept of capital in Principles (1871) and in "Zur Theorie des Kapitals" (1888). The fifth section brings the final considerations.

\section{The Classical authors}

\subsection{Adam Smith and the role of capital in production}

Adam Smith is regarded as the father of modern Economics, the founder of a whole new science branch. His book On the Inquiry on the Wealth of Nations touched many different topics 
and influenced all economists thereafter. One of these topics is capital, which is extremely important for understanding the social system then in formation: capitalism. The present section is based on Smith's Wealth of Nations, published in 1776.

In a market economy, people do not depend on the benevolence of producers to satisfy their needs, but rather on the self-interest of everyone involved in production. People fulfill the wishes of others to achieve their own goals, not because they sympathize in any way with their needs. In the development of life in society, cooperation proved to be able to multiply production and, consequently, facilitate the satisfaction of needs. This cooperation resulted in the division of labor, which paved the way for specialization and dedication to an occupation that represents a talent or natural inclination, allowing for the exchange of work surpluses among individuals in society.

In a society with a fully implemented division of labor, the work product of a single individual does not, if only partially, meet his needs. Therefore, the product of his work is exchanged for the product of the work of others. However, this exchange is only possible when the product is completed and sold. Before carrying out the work and selling the product, a certain stock of goods must be accumulated for subsistence, in addition to the materials and instruments necessary for production. The division of labor, then, is not possible without this prior accumulation of stock, i.e., without savings. The general stock of the society is divided into three parts, two of which are capital. The first one is "reserved for immediate consumption, and (...) affords no revenue or profit" (SMITH, 1981 [1776], p. 281); the second is fixed capital and affords revenue without circulating; the third is working capital and affords profit by circulating.

Capital accumulation precedes the division of labor. So, the subdivision of labor is greater when more capital is available. Generally, savings are sufficient only for a short period, being consumed in the most economical way possible to acquire something with one's work to replace it. When sufficient savings are maintained for a long period, greater income is expected from that capital: part of it is used for immediate consumption until that income begins to enter.

Therefore, savings are divided into two parts: a stock reserved for immediate consumption, which does not generate income; and another from which income is earned, called capital. Capital, in turn, is divided into two parts: fixed and working capital. Working capital is used to obtain, manufacture or buy goods, and sell them at a profit. This capital does not generate profit for those who use it until it is exchanged for money. Working capital leaves in one way, returns in another, and only generates profit by these successive exchanges. Fixed capital generates profit by investment in fixed assets like machinery, land improvement, etc. This form of capital does not change when used in the production process, but it deteriorates.

Fixed capital is subdivided into four items: machines and instruments that facilitate and shorten work; buildings that constitute means of income, both for those who receive and those who pay the rent; land improvements; inhabitants' useful skills, which are a real expense and constitute fixed capital. Smith (1981 [1776], p. 282) presents here an embryonic concept of human capital as that part of the fixed capital understood as "acquired and useful abilities of all the inhabitants or members of the society". Working capital is also divided into four items: 
money; the stock of provisions for later sale, from which profit is expected; materials necessary for the manufacture of other products; finished products which have not been sold yet.

The only goal and purpose of capital, both fixed and circulating, is to increase the stock dedicated to immediate consumption. However, working capital is the most important. Fixed capital is originally derived from and maintained by working capital, besides needing it to provide income. For the same reason, income needs working capital.

Decisions on where to invest capital are guided solely and exclusively by considerations about profit. They have nothing to do with the amount of labor that capital can handle or its value to the country's production. Capital will be invested in a sector in which it can generate greater profits. Every individual strives to apply his capital in the most advantageous way possible for him, not society's. However, the individual advantage will be greater the more his capital application benefits society.

The value of annual production can only be increased with productive work, which depends on better machines and/or more appropriate labor division. Either way, these factors depend on adding capital. The capital gradually accumulated by the frugality and sound administration of free individuals to improve their own conditions is what sustains the progress of a nation.

The effects of business mismanagement, even though it employs productive labor, are just as damaging as those of squandering, since it results in loss of capital and reduction in productive funds. However, individual maladministration is far less in number than successful ventures. Although squandering and individual recklessness do not generally result in the impoverishment of a nation, the government, by employing almost all public income in unproductive labor, poses more danger. Either way, frugality, and good governance are enough to make up for the misfortunes and waste of both individuals and governments. Everyone's uninterrupted effort to improve their own condition is the principle of national wealth and is powerful enough to maintain the natural course towards improvement.

\subsection{David Ricardo and the endless search for profit}

David Ricardo was probably the greatest political economist of the early 19th century and, as Smith, influenced all economists that came after him. As with all authors from the classical tradition, Although in his considerations, Ricardo departed from a theory of value based on labor, and spoke less about capital. Since Smith investigated the correlation between capital and economic growth, Ricardo's concern shifted to a different problem: the distribution of income (LEWIN, 2011). The following paragraphs are based on Ricardo's On the Principles of Political Economy and Taxation, published in 1817.

Ricardo (1937 [1817], p. 53) defines capital as "that part of the wealth of a country which is employed in production, and consists of food, clothing, tools, raw materials, machinery, etc., necessary to give effect to labour." Even in the most primitive stages of economic activity, namely, hunting, fishing, and gathering, individuals produce and accumulate some necessary capital for their work. Even the simplest activity requires some capital to be carried out. At each stage of society, the capital employed in different activities, such as tools, implements, 
buildings, and machinery, has varying degrees of durability and requires different amounts of work to be produced.

These different degrees of durability determine the kind of capital. Capital is fixed or circulating depending on how quickly it perishes, how often it is reproduced, or how slowly it is consumed. In describing the type of capital employed in different activities, Ricardo (1937 [1817]) uses a language that implies that the capital of one activity is fixed or circulating in relation to another activity. However, this division and distinction between types of capital are neither necessary nor essential for him.

The adjustment of capital distribution by price fluctuation occurs through profit rates. The capitalist class, including bankers, lives off the interest on their money, which takes the form of circulating capital present to varying degrees in all economic activities. The capitalists are always looking for the most advantageous application possible. As long as there is free movement of capital, they will use it in the most appropriate way. Thus, if prices in a sector rise or fall, profits increase or decrease, stimulating the entry or exit of capital in it. However, profit itself is not an objective measure, which any capitalist in any situation invariably pursues: the notion of profitable use of resources is, in a way, inherent to the capitalist himself, who considers, in addition to monetary gain, factors such as security, simplicity, ease, or any other real or imaginary advantage that a job may have in relation to another.

Capital circulates through the capitalists. Demand reduction in one sector does not mean that the producer will transfer his capital to another business, but that he will fire workers and interrupt his demand for loans. These do flow from one business to another. Conversely, the producer who sees the demand for his product increase seeks more loans to employ more workers. In this way, capital is transferred from one sector to another without a producer necessarily abandoning his occupation. Besides, the adjustment of profit rates in the different sectors is due to its reduction in the initially favored one, which temporarily experienced extraordinary profits. The competition between capitalists tends to normalize prices, or return prices to their natural levels.

At first, the relation between the amount of capital and its value is not evident. Capital increase may occur concomitantly with the increase or decrease in its value. The value of capital depends on the amount of labor required to produce it. Society's progress depends on capital accumulation, which presses and raises wages in the labor market. Keeping this higher level of wages depends on the natural price of labor. In other words, wages will only remain high insofar as basic goods, in which wages are spent, suffer permanent increases in their prices. Ricardo (1937 [1817], p. 61) argues that wages, like any other contract, "should be left to the fair and free competition of the market, and should never be controlled by the interference of the legislature."

It is not only normal, but essential that current prices fluctuate temporarily. The rise in profits attracts capital for a given activity until the rate of profit is balanced with that of other sectors and, in Ricardo's (1937 [1817], p. 205) words, it is "the inequality of profit which is always the inducement to remove capital from one employment to another". It is also possible in a market economy that profits in a given activity increase while the overall rate of profit falls. 
Such temporary fluctuations do not invalidate the argument that profits depend on wages, and wages depend on the prices of essential goods.

The motivation for capital accumulation is profit. Nobody accumulates except to make their accumulation productive, that is, profitable. While the worker depends on the salary, the tenant and the producer depend on the profit. Accumulation would cease if the profit were not high enough to offset the efforts and risks of productive use of capital.

The rate of profit does not in any way depend on the best division of labor, the invention of machinery, the construction of roads, or any other means of saving labor. These aspects influence the prices of goods and benefit consumers, by allowing the same work to generate more goods. Likewise, foreign trade is beneficial, as it increases the quantity of goods and reduces their prices, encouraging savings and capital accumulation. However, profit is not affected by domestic progress or foreign trade. The only way to raise profits is to cut wages, which does not affect the price of goods. So, profits are residues of the cost of production, especially labor.

The free trading system is fundamental to the universal good. Each country has different natural potentials, dedicating its capital and work to the most beneficial activity. The distribution of capital and labor more efficiently and economically, according to the potential of each country and duly rewarded, generates a greater offer of products to all participants in the market. Thus, each country specializes in producing that good whose results are the most advantageous. From that production, the goods whose domestic production would be inefficient are imported. This theory even applies when the same country produces both goods more efficiently.

The differences between countries are explained by the difficulty of transferring capital from one country to another in search of the most profitable application. Although profits tend to equilibrium within a country, the same does not happen between different countries, since the circulation of capital and labor between them is not as free as domestically. Thus, a country with greater technical capacity and better machines produces certain goods with less labor than its neighbors. In exchange for these goods, it imports, for example, part of the cereals necessary for its consumption, even though its land is more fertile and can produce them with less labor than in the country from which they are imported. Therefore, Ricardo's law of comparative advantages concludes that international trade is advantageous for all countries involved, even if a single country is superior in the production of all the goods in question. Thus, as long as there are profitable investments, there will be no downtime or idleness of capital.

\subsection{Stuart Mill: capital is what employs the worker}

James Stuart Mill is still in the classical tradition, despite not being contemporary neither to Smith nor Ricardo. Mill heavily influenced the Marginalist authors, especially Jevons. His book Principles of Political Economy was originally published in 1848 to update Smith's Wealth of Nations "to the more extended knowledge and improved ideas" of the time. For Mill (1871 [1848], p. 5), "the Wealth of Nations is in many parts obsolete, and in all, imperfect". Mill 
(1871 [1848], p. 68) considers the function of capital in production of "the utmost importance thoroughly to understand, since a number of the erroneous notions with which our subject is infested, originate in an imperfect and confused apprehension of this point." The present section develops the concept of capital based on Mill's Principles.

Stuart Mill begins his book describing the natural forces of production, which he calls the primary and universal requisites of production: labor and land. Then, capital becomes the third factor of production and is defined as an accumulated stock of products of previous labor. Without capital, there is no production beyond the primitive industrial activities of people. Capital is the product of past work designed to provide present production with its prerequisites. Mill (1871 [1848], p. 68) exemplifies such prerequisites of production as "shelter, protection, tools, and materials which the work requires". Also, capital serves "to feed and otherwise maintain the labourers during the process".

Just as there can be no work beyond what nature makes it possible to process and consume, there is also no work beyond the amount of capital available for investment. In this sense, labor is limited by capital. There is no more productive labor than the portion destined for its maintenance can feed and provide materials and instruments of production. However, capital alone is not a productive force, but only work and natural agents. So, there is no productive force of capital without work.

The limit of wealth is not established by the absence of consumers. Instead, wealth is limited by the lack of producers and productive force. Increasing capital provides more employment or higher remuneration, enriching the country. Thus, increasing capital increases production by employing more workers or increases the participation of workers in production by raising their remuneration. Every capital increase gives more employment to work or is capable of giving it. Although the new capital is used in machines, and not to keep workers, human beings able to work may find space in production, as long as there is food to maintain them.

Following Smith's liberal tradition, Mill (1871 [1848]) argues that a misunderstanding of the production process, that is, that labor does not depend on capital, leads one to believe that the State, through laws and taxes, can increase production without necessarily increasing the number of workers or their efficiency. For example, by banning imports of certain goods to increase their domestic production, people do not understand that it only results in the transfer of capital from some sectors to others, capital that would otherwise employ at least as many workers right now.

By abstaining from consuming and saving, the capitalist transfers his consumption power to the workers he employs. Every capital increase results from savings. Even in simple societies, one must save to continue producing, i.e., consuming less than everything produced. For example, farmers must set aside part of their production for sowing, and they must save even more if they want to employ other workers or increase production. Although saving means consuming less, this does not need to occur in absolute terms in order to increase capital, since it can be increased by raising production.

All the means employed to maintain and perform work other than its own originally come from savings, or abstaining from consumption. However, it does not mean that what is saved 
will not be consumed; it only means that it will not be consumed by those who saved. The concept of savings is essential to Mill and, if not well understood, would lead to the mistaken belief that saving means hoarding, which is not beneficial to society. On the contrary, such mistaken belief leads to an understanding that consumption means distributing benefits to third parties. This understanding is extended as a virtue even to those who not only spend their own income, thus destroying their own capital, but also spend unproductively what they borrow, thus destroying the capital of others.

In fact, savings and consumption are similar only in the first stage, when the former buys tools, raw materials, and food for workers, while the latter buys drinks, belongings, and furniture. However, what was consumed is destroyed right there; the first stage is also the last, and the amount of product disappears. What was saved put workers into action and replaced destroyed materials, reproducing what was spent. Thus, society becomes richer when it spends to maintain productive work and is poorer by what it consumes in its pleasures and amusements.

Influenced by Smith, Mill argues that manufacturers and workers do not produce to satisfy their customers, but to meet their own needs. They also demand what they produce and, having the essential elements of production, capital and labor, produce whatever is demanded. The employment of labor is not ensured by buyers, but by capital. Demand for goods does not mean demand for labor. What employs labor is capital and not consumption. Consumers determine only in which sector labor and capital will be applied, that is, the direction of production. In other words, the consumer does not provide workers with jobs, but decides in what kind of work they will be employed.

By abstaining from buying consumer goods to pay wages, a capitalist does not reduce the amount spent in society. If he used to buy wine, now workers buy goods for their subsistence. By not consuming, he transferred consumption power to the workers he employed, leaving a larger portion of the existing products to be consumed by others. When the advantages of saving are not understood, there is a contradiction: why tax to distribute to the poorest, if unproductive spending benefits them the same way?

Stuart Mill also differentiates between working capital and fixed capital. Working capital fulfills its function in the production for a single use, by not being conserved, but passed on from one owner to another. On the other hand, fixed capital consists of relatively permanent instruments of production, the effect of which is not produced by their sale, but by their conservation, and whose effectiveness is not limited to a single use. The difference between the effects of working capital and fixed capital is that circulating capital, being destroyed in a single use, creates a product capable of replacing it and generating a profit for its owner. This is not the case with fixed capital.

Mill argues that the introduction of machines, or the capital investment on permanent improvements, does not, if only temporarily, make workers suffer. In fact, the improvements in production are not harmful to workers. They occur gradually and do not come from funds already invested as working capital, but from annual production increases. That is, increases in fixed capital generally occur concurrently with increases in working capital. 


\section{The Marginalist authors}

\subsection{The free capital of Stanley Jevons}

Willian Stanley Jevons was one of the three authors that contributed to the Marginalist Revolution. He died before fully developing his theory, but he laid its essential elements (HAYEK, 1941). Jevons' theory of capital is associated with the Austrian theory of capital, as it influenced authors such as Eugen von Böhm-Bawerk (1851-1914), Knut Wicksell (1851-1926), and Friedrich Hayek (1899-1992) (OLIVA, 2015). The following section is based on Jevons' The Theory of Political Economy, published in 1871.

Jevons' admitted task is to give a different and much simpler definition of capital. For this, he dedicates the seventh chapter of his book, in which he develops his theory of capital. Firstly, Jevons makes it clear that capital and exchange have no necessary relationship with each other. Both allow men to increase utility, but it is possible to have the advantages of capital without those of exchange. He cites Alexander Selkirk's economy as an example, whose true history gave life to the myth of Robinson Crusoe. In Selkirk's economy, capital is used to produce, but not for exchange purposes. This reasoning can be extended to affirm that production and exchange also have no necessary relationship with each other. If capital has the function of assisting production, there is no reason to confuse it with any compelling notion of exchange.

Agreeing with Ricardo's theory, Jevons (1965 [1871], p. 223) believes capital consists of the wealth used to facilitate production. More specifically, capital is"in the aggregate of those commodities which are required for sustaining labourers of any kind or class engaged in work". In this sense, he admits the strong influence of Stuart Mill, to whom he credits the argument that goods necessary for subsistence are an essential part of capital. Based on Mill, Jevons (1965 [1871], p. 312) defines capital "as consisting of all useful objects which, in supplying a labourer's ordinary wants and desires, enable him to undertake works of which the result will be deferred for a greater or less space of time. Capital, in short, is nothing but maintenance of labourers".

The unique and fundamental function of capital is to enable the worker to wait for the result of production. Capital makes it possible to spend work in advance; the first part is spent making instruments that help the rest of the work, so that it does not depend only on bare hands.

Without capital, a person must have immediate returns, or else he perishes. With capital, he may sow in the spring that he may reap in the autumn; or he may undertake laboursaving enterprises, such as roads and railways, which will not make a full return for many years. Most improved modes of applying labour require that the enjoyment of the result shall be deferred. (JEVONS, 1965 [1871], p. 312)

Jevons sketches a production process with his definition of capital, which influenced many authors and is even regarded as part of the Austrian capital theory (HAMBERGER, 2001). The division of labor allows production using instruments previously produced. The 
production process consists of different stages, and there is always the use of capital to facilitate it, or even make it possible. Capital is spent on buying the instrument produced on a previous stage, which probably used capital in the expectation to sell the product. The capital of one replaces that of the other, and the labor expenditure begins long before the final product is finished. Improvements in the production process, made by using capital, increase the interval between the beginning of the execution of the work and its consummation. All capital uses are reduced to the time elapsed between the beginning and the end of the activity.

By defining capital as the maintenance of laborers, Jevons does not ignore produced means of production as part of capital. But he considers such assets as a consequence of its use. In Jevons (1965 [1871], p. 312) words, it is "true that buildings, tools, materials, etc, are necessary means of production; but they are already the product of labour assisted by capital or maintenance. They result from the application of capital to labour at an imperfect stage". To those assets, or the current means of support, Jevons associates the concept of free capital, that is, uninvested capital.

For Jevons, free capital is the most useful concept, since differentiating between working and fixed capital is difficult. Following Ricardo's distinction, circulating capital is that consumed in less time. Thus, the least durable capital is called working capital; the most durable, fixed capital. To avoid the difficulties of differentiating between working and fixed capital, Jevons introduces the concept of free capital - meaning the worker's salary, or what he needs to survive while producing.

Therefore, free capital consists of the transitory form of money, in the real form of food, clothing, etc. Its fundamental principle is that it can be used in any economic activity, and in that sense, it is free. Jevons (1965 [1871], p. 243) goes on to say that "the ordinary sustenance requisite to support labourers of all ranks when engaged upon their work is really the true form of capital."

For example, in the language of commerce, it is not said that railways, machines, etc., are capital, but that capital is tied to the enterprise. Capital is the food of the workers who made such assets. Jevons (1965 [1871], p. 243) adopts a similar approach here: "I would not say that a railway is fixed capital, but that capital is fixed in the railway. The capital is not the railway, but the food of those who made the railway". Thus, capital is abundant in a country with abundant stocks of workers' subsistence goods, allowing the production of goods whose utility is not immediate without the feeling of scarcity at present.

Although Jevons' theory of capital has some similarities to Ricardo and Smith's, there is a fundamental difference. Jevons considers those goods held by the final consumer as capital. For instance, Smith distinguished community reserves into three parts: working capital, fixed capital, and stocks. The latter, however, are reserved for immediate consumption and do not provide income or profit. Therefore, Smith concludes that the same assets, serving the same purposes, are capital depending on who owns them. This conception seems to be based on the notion that capital must yield or increase wealth. Jevons, however, questions this conclusion, arguing that, just as the land yields wheat, wool, etc., houses yield income for shelter and 
comfort. The purpose of economic activity is to satisfy our needs, so that what produces them must also be called capital.

There is nothing to separate certain assets as being capital or not. Capital is the power to postpone the consumption of the fruits of labor, satisfying the worker in the present instead of getting him to produce for momentary needs. Now, all pieces of property contribute to capitalization. As classical economists argue, capital is wealth used to produce more wealth. However, the same good has different uses. The concepts of capital or capitalization must be applied to the use of the thing, not the thing itself.

Capital empowers labor before its result is needed, which facilitates production. The total sum of the country's capital is made up of the total of things that satisfy the needs of individuals. Thus, capital is not the product of past labor, but it is wealth used in a certain way for a specific purpose, regardless of its origin. Capital consists of all useful objects that supply the worker's needs and desires, allowing him to undertake work whose result will take place in the distant future. Many improved ways of applying work require present satisfaction to be postponed. Capital is the livelihood of the worker.

\subsection{Walras and the distinction between capital and income}

Leon Walras is the French representative in the Marginalist Revolution. Having founded his theory on the idea of general equilibrium, he influenced what is known as the Neoclassical school and is the most present author of the Marginalist Revolution in today's mainstream economics. Based on his Elements of Pure Economic, published in 1874, this section investigates Walras' concept of capital.

Walras denies the concept of social wealth as the foundation of his theory. Social wealth is the set of useful material and immaterial things, which are rare and, thus, limited. Useful means that it serves to attend to a need or allow its satisfaction. Limited means that, although it is at one's disposal, it does not exist in a quantity that each individual can have at his disposal and at will to satisfy his need for it. Although useful, the unlimited things are not rare and, thus, do not take part in the social wealth. For Walras, the morality or immorality of the need to which the thing is useful does not matter, which clearly shows a subjectivist approach.

For Walras, the three elementary factors of production - labor, land, and capital - are not rigorous enough to allow for rational deduction. To this end, Walras proposes a distinction of social wealth between capital, or durable goods, and income, or non-durable goods. Capital goods can be used more than once, while income goods can only be used once. He inherited such distinction from his father, August Walras, author of Théorie de la Richesse Sociale, written in 1849 , to whom capital is any durable good that is not consumed at once.

Capital is all part of the social wealth consumed in the long run. More precisely, capital here is short for fixed capital, and Walras cites houses and furniture as examples. On the other hand, income are fungible goods immediately consumed, not subsisting after its first service. Income is understood as circulating capital, and Walras cites bread, meat, agriculture, and industrial raw materials, such as seeds and textiles, as examples. 
Therefore, the distinction between capital and income, or fixed and circulating capital, resides on the duration of the good. However, Walras clarifies that he refers to its economic, not its material or technical duration. For instance, textiles materially subsist in the cloth after their first use, but not as industrial raw material to be used in production again.

Although certain kinds of social wealth do by their very nature attain the character of capital or income, capital and income concepts do not apply permanently to a large part of the different species of social wealth. Walras takes trees as examples. When trees give fruits, they are capital. However, when they are cut down for lumber, they are income.

When one refers to consuming capital, that means first trading capital for income and then consuming it. On the other hand, when it comes to capitalizing incomes, it is first necessary to trade income for capital. In this sense, Walras warns against confusing capital with provisions - sums of income anticipated for consumption. For instance, the mines are capital, but the minerals in it are provisions. The essence of capital is to generate income, and the essence of income is to be generated by capital. Since capital, by definition, survives its first use, its successive uses are a succession of incomes. Each use of capital means a generation of income. Walras (1954 [1874], p. 213) gives different examples: a piece of land is capital, while the fecundity for our harvest is its income; a house is capital, while the shelter it provides is its income. The same applies to a lawyer and is consultations or a machine and its use.

The use of capital and the consequent generation of income must be distinguished into kinds of services. Consumer's services are those utilized in public or private consumption, such as the shelter of the house or the lawyer's consultation. On the other hand, producer's services comprise those transformed into products. By means of agriculture, industry or commerce, these services are transformed into incomes or capital, such as the fertility of the land or the use of the machine. Walras' (1954 [1874], p. 214) distinction of consumer's and productive services corresponds to unproductive and reproductive consumption. His concern, thus, is "with the study of the transformation of productive services into products."

After defining capital and income, Walras divides social wealth into four main categories, three of which are capital and one of income. The first of the four categories is land. All kinds of land are capital: from the parks and gardens for leisure to the land where houses and factories are built; from the pastures and fields where men create animals and produce fruits and vegetables to the streets and channels that communicate people throughout the country. Land subsists to its first use, and its successive use constitutes its income. Walras (1954 [1874], p. 214) defines this first category of capital as landed capital or simply land, which is capable of yielding land-income or land services, also called rent.

From the people who only live an idle life to the people who engage in liberal professions, from public officials at the service of the State to private workers at the service of the industry: all people are capital. All people survive after the first service they render, and such services constitute their income. Walras (1954 [1874], p. 215) defines the second category of capital as personal capital or simply persons, capable of yielding personal incomes or services of persons, known as labor. We should not confuse the Walrasian definition of persons as capital with 
the concept of human capital, which is nonexistent in his book in the way Smith, for instance, developed in his Inquiry to the Wealth of Nations.

All the remaining capital assets, which are neither land nor people, are considered proper capital: from private houses and public buildings to plants and animals; from paintings and furniture to tools and machines. Walras (1954 [1874], p. 215) considers proper capital the third category of capital, capable of yielding capital-income or capital-services, also called profits.

The fourth category of social wealth is income, which Walras (1954 [1874], p. 215) divides into two groups. The first group is composed of consumers' goods, such as beer, fruits, and bread. The second is composed of "all things destined to disappear as raw materials only to reappear as products", such as seeds, lumber, and textiles. Walras' categories of social wealth and his examples make clear the strong influence of the Smithian concept of capital. As such, they do not represent a disruption in the field.

\section{Carl Menger}

\subsection{Menger and the de-homogeneization of the production process}

Carl Menger is considered the founder of the Austrian School of Economics, having influenced economists like Eugen von Böhm-Bawerk, Friedrich von Wieser, Ludwig von Mises, and Friedrich Hayek. His influence goes beyond the Austrian tradition, as he was part of the Marginalist Revolution, contributing to the subjective theory of value and the marginal analysis. Menger based the teaching of Economics on the individual and human action.

Menger did not properly develop a capital theory in his magnum opus, Principles of Economics, published in 1871, apart from a lengthy footnote in the third chapter. It is assumed that Menger's Principles is the departure point for an "Austrian" theory of capital, despite its elements already being present on classical authors (SILVA et al., 2014). Nevertheless, there are plenty of contributions to a concept of capital that would later serve as the basis for an "Austrian" one. The following section is based on Principles, sketching Menger's first concept of capital.

Initially, Menger explains that all things are subject to the law of cause and consequences. If an individual is to satisfy his needs and desires, he must combine his own forces with the forces of nature on his behalf to create the conditions, or causes, that will result in the desired consequences. Things that will satisfy human needs are goods. In this sense, to attain the quality of good1, a thing must meet four conditions. First, it must exist as a human need or desire. Second, the properties of this thing must be adequate and have a causal relationship to the satisfaction of the human need. Third, such causal nexus must be recognized. Fourth, it must be available. A fifth condition - that the good must be scarce - gives it the quality of an economic good.

\footnotetext{
${ }^{1}$ Menger uses the expression "Güterqualität", literally translated as "quality of goods". The present paper uses as translation both "quality" and "character" interchangeably.
} 
The causal aspect of a good with the satisfaction of human needs is one of the preconditions for its quality. However, it is not a prerequisite for the quality of a good that it be directly related to the satisfaction of human needs. Declaring that something has the quality of good implies that it attends to some human need, but it does not mean a direct relationship. On the contrary, goods sometimes have a closer causal relationship to the satisfaction of needs, sometimes a more distant one, without losing their character of good. These goods, concerning the satisfaction of human needs, sometimes directly, sometimes indirectly, are distinguished between first, second, third (...) orders. Goods of lower orders satisfy human needs more directly, while goods of higher orders satisfy them more indirectly. As the good moves away from direct satisfaction, it increases in order.

First-order goods are those goods that can directly satisfy human needs and desires. On the other hand, second-order goods or higher cannot do it. Even though higher-order goods cannot directly satisfy human needs, they are considered goods because they can be transformed into first-order goods.

Unlike first-order goods, higher-order goods can only attain the quality of good if one has the corresponding complementary goods of higher-order at his disposal. Because higherorder goods can only satisfy human needs indirectly, after being transformed, they must be combined with other goods of the same order. Such considerations lead Menger (1871, p. 15) to formulate the "law of mutual dependence of goods", that is, to produce a first-order good, higher-order goods depend on the availability of complementary goods of the same order. Otherwise, they cannot attain the character of good.

A single higher-order good cannot satisfy one's needs, in this case indirectly, until the complementary goods of the same order, which human labor use together in production, are available. As a result, therefore, their character of good depends on this availability.

For example, a coconut tree can be a good for an individual lost in a forest. It satisfies the four conditions listed above: the individual is thirsty; the coconut tree has coconuts, which he can feed on; the individual knows that, when he reaches the coconut water, he will end his thirst; coconut trees are available in the middle of the forest. However, if he cannot gather and cut open the coconut, the coconut tree will not satisfy his need and, therefore, will not be considered a good.

Complementary goods are needed for production to be viable. In the previous example, a stick and a knife would be useful. Of course, human labor is also a complementary higherorder good. If the individual does not have instruments of this type, which are indispensable for gathering coconuts and extracting water from them, an acre of such trees will not attain the quality of good at all.

The transformation of goods of higher-order into goods of lower-order takes place in time, like every other process of change. Production is a transformation process, and the economy can be imagined as a system of transformations of higher-order goods into lower-order goods. The quality of good is not inherent to the product, but it is in the individuals' subjective evaluations, on how the object is interpreted in relation to the possible satisfaction of needs. Likewise, the position of a good in the production process, whether it is a good of a higher or 
lower order, is not inherent in the good either, being also the result of subjective evaluations. The law of mutual dependence of goods means that individual higher-order goods, such as machines and raw materials, are not homogeneous. Instead, they occupy different stages in the production process, depending on the view of those who conduct it. By this definition, Braun (2015) considers that Menger de-homogenized the production process.

The de-homogenized production process helps to explain the economic development of societies. Developed societies are characterized by the lengthening of the horizon of economic planning. While individuals living in simpler societies are concerned with planning their lives within a period of time not much longer than weeks or months, others in more advanced societies plan their future decades in advance. The lengthening of the economic planning time horizon means longer production processes. Individuals in an advanced society start a production process that will only be completed years later. The final product, the consumer good that will directly satisfy human needs, or, in Menger's expression, the first-order good, will be ready for consumption only years after the start of the production process. In short, the characteristic of developed societies is the extension of economic planning and, consequently, of the production structure.

The extension of the employment of higher-order goods, which causes a continuous expansion in the availability of consumer goods, is only possible when men expand their thrifty activities to ever more distant time periods. Such provident activities mark the cultural development (Culturentwicklung) of men, as Menger (2007 [1871], p. 153) exemplifies:

A primitive Indian is occupied incessantly with the task of meeting his requirements for a few days at a time. A nomad who does not consume the domestic animals at his command but decides to breed them for their young is already producing goods that will become available to him only after a few months. But among civilized peoples, a considerable proportion of the members of society is occupied with the production of goods that will contribute only after years, and often only after decades, to the direct satisfaction of human needs.

It is proper at the beginning of a new development phase that individuals use goods of the next higher-order, lengthening the horizon of their economic plan. Part of these goods already existed, despite not having any economic application until then. Given that they were not scarce, such non required goods had the quality of goods, but not economic goods. Under this new development phase, such goods start to be used in the production process, but still do not attain the economic character. On the other hand, part of the complementary higherorder goods already attained the economic character, as they served to satisfy human needs before the lengthening of the production process.

Thus, Menger explains that what prevents progress in the employment of higher-order goods to satisfy human needs is not the limited quantities of goods. Instead, the progress of economizing men is limited by the subjective choice of employing available goods to satisfy human desires only in a more distant period of time. This means that goods are already available for individuals, but they are being used for a production process that will end in the future. The subjective change of individuals is what allows for economic progress. For this reason, Menger refers to such progress as "Culturentwicklung", that is, cultural development. 
In this context, Menger defines capital. He says that, with the continuous development of civilization, individuals can only participate in such progress if they have command of capital, which he defines as quantities of economic goods of higher-order in the present for future periods of time. Menger also considers capital economic goods of any kind, when a brisk commerce has already developed, and goods of all kinds may be exchanged freely.

However, Menger is cautious with his definition. Command of capital cannot contribute by itself to the increase of consumption goods. Instead, command of capital is a means to the better and more complete satisfaction of their needs. In other words, capital must go through a transformation process until it becomes first-order goods, but the command of capital alone does not guarantee this process.

On a two-page footnote, Menger expands his view on capital. Instead of focusing on the technical issue, capital must be understood in economic terms. Therefore, "the classification of goods into means of production and consumption goods (goods of higher-order and goods of first-order) is scientifically justified but does not coincide with a classification of wealth into capital and non-capital" (MENGER, 2007 [1871], p. 303). Also, capital does not refer to all items of wealth that permanently yield an income. In other words, capital is not equivalent to production goods (BRAUN, 2015).

Then, Menger repeats the definition of capital he gave in the main text: quantities of economic goods available in the present for future periods of time. To be considered capital, such quantities of economic goods must simultaneously satisfy two conditions. The first condition is that capital must be available for the long production process, in the economic rather than in the technical sense. If the quantities of economic goods are available only for a short period of time, soon losing their productivity, they are not capital. The second condition is that the economizing men, through the amounts and kinds of goods available, must command the complementary goods necessary for transforming higher-order goods into lower-order goods.

Menger also points out that higher-order goods per se are not capital, but only combinations of them (BRAUN, 2015). This represents the main difference between capital and items of wealth that yield an income: the latter are durable goods; the former is a set of complementary higher-order goods. The service of durable goods has by itself the quality of economic good. They can be considered capital only when combined in a production structure.

In the final part of his footnote, Menger critiques what he calls a much too narrow concept of capital, which calls it sums of money. In developed economies, where trade is extensive, capital is regarded in terms of money. Because of such convenience to require and trade for it, capital is mistakenly interpreted as sums of money in ordinary life. What is all but a particular form of capital has been regarded as the concept itself, because businessmen, especially, do not reckon capital heterogeneously (BRAUN, 2015). This narrow concept is contrasted by another mistaken concept of capital, in which the money form is not considered capital at all.

On the one hand, such opposing views on capital are explained by a mercantilist concept; on the other, by its opponents. Menger settles the question by defining sums of money only as a convenient form of capital suitable for trade. By quoting Karl Knies, Menger (2007 [1871], p. 305) recognizes the importance of the money-capital for the economic development of 
nations, as it facilitates the transfer of capital and capital goods, and its transformation and application into any desired forms. Nonetheless, "the concept of money is entirely foreign to the concept of capital".

\subsection{Menger's revisited popular concept of capital}

Seventeen years after publishing the first edition of his Principles, Menger published a paper changing his previous view. Published in 1888, Zur Theorie des Kapitals, translated by Braun (2020) as "Contribution to the Theory of Capital", is divided into five parts. After the first four parts reflecting on four different interpretations of the concept of capital, the last part brings Menger's reviewed concept of capital. In 1888, Menger translated an abridged version of the article to French, and the original German version was translated to Spanish in 2007. Despite these translations, Menger's contribution remains somewhat overlooked, and Braun (2020) seeks to change this by translating the last part of the paper to English. The following section is based on the original German version of Menger's article, referring to Braun's translation.

Hayek (1934, p. 410) argues that Zur Theorie des Kapitals disagreed with Bawerk's definition of capital in the first part of his Capital and Interest, and that Menger's goal was to "rehabilitate the abstract concept of capital as the money value of the property devoted to acquisitive purposes against the Smithian concept of the "produced means of production"'.

Braun (2020, p. 559) conjectures that scholars of the Historical School influenced Menger's revisited concept of capital. This "change of mind" bridges this school with the Institutional school that succeeded it, and the Austrians. Petrzak (2020) notes that Menger had been confused on the subject, being closer to a common parlance concept of capital years before publishing his Principles.

In Zur Theorie des Kapitals, Menger abandons the concept of capital as a heterogeneous structure of higher-order goods. Against the traditional economics theories holding capital as produced means of production, Menger brings the capital concept closer to common parlance. By this approach, Menger distances himself from what is usually understood as the Austrian capital theory, but foreshadows Mises' concept of capital. In fact, Menger and Mises were closer to an institutional theory (BRAUN et al., 2016).

By common parlance, Menger (1888) means the language of businessmen, who interpret capital as a homogeneous concept, as sums of money on ordinary business accounts. Mill (1871 [1848], p. 68) had already dismissed this interpretation of capital as synonymous with money, calling it a "misapprehension". Menger (2007 [1871], p. 304) himself had considered the homogeneous concept of capital as "much too narrow" in Principles. Therefore, Menger's (1888) new concept is a clear turning point in his interpretation.

For Menger (1888, p. 2), it is an error, which "cannot be disapproved of enough", when a science uses expressions already popular for essentially different categories of phenomena. By adopting a concept of capital in a narrower or broader sense, but in all different to common life language, economic scientists cause confusion and ambiguity. In fact, Fisher (1904) unavoidably 
reinforces Menger's theory, recognizing that the definitions of capital before Adam Smith were all different from the scientific one, but still present in the business language.

In his view, capital was not supposed to be understood from its technical sense and thus related to the production process. Capital is not a heterogeneous production factor, but rather a homogeneous character expressed in terms of money (BRAUN, 2015). The realistic concept of capital relates to economic goods, independent from their technical nature, of which its value is calculated in terms of money. Menger $(1888, p$. 40) considers capital as sums of money that generate income and are expressed in business accounts. In other words, capital is the object of economic calculation and is understood as money and all sorts of goods that appear as monetary sums in business accounts.

Menger (1888, p. 4) starts his article by investigating the different basic concepts of capital in Economics. From the microeconomic (Singularwirtschaft) viewpoint, capital theories are divided into three groups. The first refers capital to an individual's wealth devoted to income generation in contrast to reserves for use. The second, capital as the means of production in opposition to the products themselves. The third, as products devoted for production as opposed to other kinds of goods that participate in production (natural goods and labor). This third group is also referred to as the conception of capital as produced means of production. In Macroeconomics (Volkswirtschaft), Menger (1888) criticizes the concept of capital from the standpoint of society.

Menger (1888) dismisses the first microeconomic concept of capital, that of wealth dedicated to the acquisition of income, saying that such theory disregards the complexities of the income phenomenon. This viewpoint focuses on the etymology of the word capital, not collaborating directly to a theory of income (BRAUN, 2015).

The second notion is of capital as means of production. Menger advocated a similar concept in his Principles, being further developed as the "Austrian" capital theory. Because of this, Braun (2015) considers it relevant to understand this viewpoint. Menger (1888) does not throw away all he said in his Principles. In fact, he reinforces the relevance of the classification of goods into lower and higher orders, according to the proximity of the direct satisfaction of human needs, warning that such distinction does not coincide with the classification of goods into capital.

Menger (1888) rejects the theories that take higher-order goods, a combination of higherorder goods, or a heterogeneous structure of them as capital, regardless of these goods being produced or not, because such theories refer to the technical instead of the economic point of view. Thus, Braun (2015, p. 86) concludes that Menger "recants what he said about capital" in his Principles. For Menger (1888), a combination of higher-order goods is used every day in households, but such combination has nothing to do with capital theory.

The third and last microeconomic concept analyzed is capital as produced means of production, a definition Adam Smith proposed. Menger (1888) opposes this view beginning with the triad capital, labor, and land. For him, such a triad is untenable, since any natural factor, to be useful for production, requires the investment of labor. In this sense, both products 
and natural factors can become capital. It all depends on the entrepreneur, and his subjective appreciation. In short, the technical origin of a production factor is indifferent (BRAUN, 2015).

The fourth theory, the macroeconomic point of view, regards capital as a term arising from individuals to the whole society as a single subject (BRAUN, 2015). Beyond the critique of considering capital from a technical perspective, Menger (1888, p. 32) also critiques the macroeconomic theory as a whole, dismissing the economy as "an economic agent itself". On the contrary, "the economy is an organism of economic agents" who make decisions respective to their individual needs, not those of the nation.

In contrast to these concepts, and after a thorough investigation to reject their errors, Menger (1888, p. 4) proposes a "realistic conception of capital", which he understands as that of business, not the scientific or economic one. By "realistic", Menger (1888) means a concept familiar to businessmen, obtained both from the observation of life and the practical occupation (BRAUN, 2020).

In short, Menger (1888, p. 37) defines capital as "sums of money that are dedicated to the generation of income". Here, sums of money are understood in the sense of "components of a person's acquisitive assets". Nonetheless, money and capital are not confused in the business language. Menger proceeds to give several examples of the use of the word money in common parlance only as an elliptical expression, such as "cheap" or "expensive" money, as opposed to the literal expression.

There are three categories of assets that Menger (1888) considers capital. The first one is interest-bearing loans, which are capital as such and consist of the most evident example. The second is actual amounts of money intended for productive investments, which are also capital. The third is business assets, regardless of their technical nature, represented as an acquisitive sum of money. The assets in the third category are capital, but only in terms of calculation.

In business language, businessmen are used to saying that a person possesses a wealth of many thousands of dollars without having a single dollar at his disposal. The same reasoning applies to capital. For instance, merchants possess a stock of goods for future sale, calculated for economic purposes in terms of money and thus considered capital. In fact, the concept of capital always rests in terms of economic calculation (MENGER, 1888).

In the broader view, capital is the corpus of the business, or its original wealth, consisting of, or calculated in money. In the narrower sense, capital is understood as all business assets, consisting of or calculated in money. When it comes to defining fixed and working or circulating capital, the distinction derives from the technical characteristic of the asset. If the component of the corpus of the business is used in production, its monetary value is called fixed capital; if it is technically consumed or sold by the business, its monetary value is called circulating or working capital.

While productive assets may still be calculated in terms of commodities in some branches of the economy, money-driven enterprises calculate in terms of money, which explains the historically earlier appearance of the capital phenomenon in them. With the evolution of monetary economies, the dichotomy between capital and land tends to disappear, since land is calculated in monetary terms, thus assuming the character of capital. 
By focusing on the evolution of monetary economies, Menger (1888) seems to refer to the development of capitalism and the consequent widespread monetary calculation. Such interpretation forms the starting point for a theory of capital that would be better suited to understand the capitalist system, in opposition to the concept of capital in Adam Smith and his successors (BRAUN, 2017).

Böhm-Bawerk (1921), after careful and repeated analysis, dedicates a few pages to investigate the concept of capital in Zur Theorie of Capital. For Böhm-Bawerk, the popular notion of capital rests in an oscillating base, as it varies according to subjective reactions. Menger (1888) recognized this as well. Notwithstanding, Böhm-Bawerk disagrees with Menger and concludes that this lack of objectivity serves no purpose in economic science.

Additionally, the popular concept of capital may represent a transitional stage from the economic enterprise with no money to that with money. If that is the case, Böhm-Bawerk (1921) argues that, on the one hand, only the linguistic usage of the term capital in the present is of interest, and, on the other, once this transitional stage is over, the popular concept loses its peculiarity, being demoted to a synonym to wealth. Thus, Böhm-Bawerk disregards Menger's (1888) popular concept in favor of the Smithian more objective and scientific concept.

Notwithstanding Bawerk's critique of Menger's concept, and the evolution of an Austrian capital theory in opposition to it, Menger was not alone in adopting a concept of capital as in the businessmen language. Mises also interprets the concept of capital in terms of economic calculation. Like Menger (1888), and in disregard of the technical point of view, Mises (1949, p. 262) defines capital as "the sum of the money equivalent of all assets minus the sum of the money equivalent of all liabilities as dedicated at a definite date to the conduct of the operations of a definite business unit". The clear distinction between the physical and the financial concepts of capital is essential for investigating the different economic phenomena. For instance, Lewin and Cachanosky (2020) develop a theory of capital that is both consistent with Mises' definition and suitable to the investigation of the business cycle from an Austrian standpoint.

\section{Final considerations}

This paper aimed to understand how different the concept of capital as in business language is from the concept of capital as produced means of production. The latter notion is usually adopted by economists that favor the technical instead of the economic viewpoint. To appreciate Menger's (1888) revisited theory of capital and fully capture the context of his writings, the paper analyzed the theories of Classical and Marginalist economists.

In bringing Menger's somewhat overlooked article to light, this paper opens a path for investigating all the implications that it poses. One of these is the theory of capitalism. The capital theory must be regarded as an inalienable part of the capitalist system. Without a proper concept of capital, there can be no correct understanding of capitalism (BRAUN, 2017). In this sense, capital as produced means of production cannot explain the specificities of the capitalist system, because means of production have been produced long before the Industrial 
Revolution. For instance, Ricardo (1937 [1817]) recognized that even the simplest activities of the most primitive stages of an economy required the use of capital. In the Austrian theory developed from Menger's Principles, capital is related to the production process per se, regardless of the prevailing economic system (ENDRES; HARPER, 2011). A better-suited analysis of the capitalist system would be the concept of capital as in economic calculation, an approach proposed by Menger (1888). Hodgson (2014) also points that the way for better understanding Capitalism is to return to the pre-Smithian notion.

The concept of capital as in common parlance becomes ever more widespread with the development of the monetary economy and business accounting. Mises (1949) favors a definition of capital as in economic calculation, which opens the field for a connection between Austrian and Institutional economic theories (BRAUN et al., 2016). Despite dismissing the popular concept of capital for being too subjective, Böhm-Bawerk (1921) admits that it would be a surprisingly simple and attractive solution. Jevons (1965 [1871], p. 243) does not take a similar path to that of Menger (1888). However, he also recognizes that "much clearness would result from making the language of Economics more nearly coincident with that of commerce".

The concept of interest generates even more debate in economics. The present paper is limited to the research on the concept of capital, without further studying the theory of capital interest, which would require a complete and most likely longer article. This endeavor presents itself as a path for future research, and the present paper can serve as the starting point for it.

\section{References}

BÖHM-BAWERK, Eugen von. Kapital und Kapitalzins: Positive Theorie des Kapitales, zweite Abteilung, zweiter Band. Jena: Gustav Fischer, 1921.

BRAUN, Eduard. Carl Menger's Contribution to Capital Theory. History of Economic Ideas, v. 23, n. 1, 2015.

BRAUN, Eduard. Carl Menger: Contribution to the Theory of Capital (1888). Journal of Institutional Economics, v. 5, n. 16, 2020.

BRAUN, Eduard. The Theory of Capital as a Theory of Capitalism. Journal of Institutional Economics, v. 13, n. 2, 2017.

BRAUN, Eduard; LEWIN, Peter; CAHANOSKY, Nicolás. Ludwig von Mises's Approach to Capital as a Bridge between Austrian and Institutional Economics. Journal of Institutional Economics, v. 12, n. 4, 2016.

ENDRES, Anthony, and HARPER, David. Carl Menger and His Followers in the Austrian Tradition on the Nature of Capital and Its Structure. Journal of the History of Economic Thought, v. 33, n. 3, 2011.

FETTER, Frank Albert. Recent Discussion of the Capital Concept. Quarterly Journal of Economics, 1900.

FISHER, Irving. Precedents for Defining Capital. Quarterly Journal of Economics, v. 18, n. 3, 1904.

FISHER, Irving. What is Capital? The Economic Journal, v. 6, n. 24, 1896.

HAMBERGER, Klaus. Böhm-Bawerk, Jevons and the 'Austrian' theory of capital: 'a quite different relation'.

The European Journal of the History of Economic Thought, v. 8, n. 1, 2001. 
HAYEK, Friedrich August von. Carl Menger. Economica, v. 1, n. 4, 1934.

HAYEK, Friedrich August von. The Pure Theory of Capital. Chicago: University of Chicago Press, 1941.

HICKS, John. Capital Controversies: Ancient and Modern. The American Economic Review, v. 64, n. 2, 1974.

HODGSON, Geoffrey M. What is capital? Economists and sociologists have changed its meaning: should it be changed back? Cambridge Journal of Economics, v. 38, n. 5, 2014.

JEVONS, William Stanley. The Theory of Political Economy. New York: Sentry Press, 1965 [1871].

KEYNES, John Maynard. The General Theory of Employment, Interest, and Money. London: Macmillan and Co., 1936.

LEWIN, Peter. Capital in Disequilibirum. The Role of Capital in a Changing World. Auburn: Ludwig von Mises Institute, 2011.

LEWIN, Peter; CACHANOSKY, Nicolás. Austrian Theory of Capital. A Modern Survey of the Essentials. Cambridge: Cambridge University Press, 2019.

MENGER, Carl. Grundsätze der Volkswirtschaftslehre. Wien: Wilhelm Braumüller, 1871.

MENGER, Carl. Zur Theorie des Kapitals. Jahrbücher für Nationalökonomie und Statistik, v. 17, 1888.

MILL, John Stuart. Principles of Political Economy: with some of their applications to social philosophy. London: Longmans, Green, Reader, and Dyer, 1871 [1848].

MISES, Ludwig von. Human Action: A Treatise on Economics. New Haven: Yale University Press, 1949.

OLIVA, Gabriel. The Capital Controversy of Hayek-Knight. MISES: Interdisciplinary Journal of Philosophy, Law and Economics, v. 3, n. 2, 2015.

PETRZAK, Yannis. An Outline of Carl Menger's Capital Theory 1867-1888. Paper presented at the Austrian Student Scholars Conference 2020, Grove City, 2020.

RICARDO, David. The Principles of Political Economy and Taxation. London: J. M. Dent and Sons Ltd, 1937 [1817].

SILVA, Felipe Rosa da; BRANDA, Domingos Crosseti; FEISTEL, Paulo Ricardo. A Teoria do Capital e o Papel da Poupança Voluntária na Criação de Vantagens Comparativas em Bens Intensivo-Capital. MISES: Revista Interdisciplinar de Filosofia, Direito e Economia, v. 2, n. 2, 2014.

SMITH, Adam. An Inquiry into the Nature and Causes of the Wealth of Nations. Indianapolis: Liberty Press, 1981 [1776].

WALRAS, Leon. Elements of Pure Economics or the Theory of Social Wealth London: Allen and Unwin, 1954 [1874]. 